кандидат педагогічних наук

(Волинський інститут післядипломної педагогічної освіти) vsavosh@ukr.net

ORCID : $\odot \odot \odot \odot-\odot \odot \odot 1-9499-885 X$

\title{
СМИСЛОВА ЕКСПЛІКАЦІЯ ФЕНОМЕНА "НЕПЕРЕРВНА ОСВІТА": СУТЬ, МЕТА, ФУНКЦІЇ, ЕТАПИ, ВИЯВ НА РІВНЯХ ПРИНЦИПУ ТА ПРОЦЕСУ
}

У статті здійснено наукове пояснення суті поняття "неперервна освіта". Аналіз тлумачень поняття

"неперервна освіта" упорядковано на основі виокремлення низки домінуючих акцентів у його трактуваннях. Складність феномена "неперервна освіта" розкрито на основі аналізу його тлумачення $i$ як приниипу, $і$ як процесу.

Також наукове пояснення суті поняття "неперервна освіта" спрямовано на впорядкування низки понять, які використовуються в наукових джерелах у контексті неперервної освіти.

Ключові слова: неперервна освіта, освіта, мета, функиї̈, етапи, принциип, процес.

Постановка проблеми. У 70-тих роках XX століття неперервна освіта у ранзі прогресивної ідеї набула законодавчої визначеності в низці документів ЮНЕСКО та у Законі США (Lifelong Learning Act; 1976 р.) як навчання протягом життя. Упродовж 70-90-х років XX століття неперервна освіта практично реалізовувалася на основі принципів концепції Т. Хюсена (Husen T. The Learning Society. L.; Methuen, 1974 р.) "Суспільство, що навчається" (learning society) та низки педагогічних моделей ("продовжувана освіта" (continuing education), "продовжувана професійна освіта" (continuing professional education (CPE)), "відновлювана освіта" (recurrent education), "громадська освіта" (community education), "освіта дорослих" (adult education), "організація, що навчається" (learning organization)).

Аналіз вітчизняних та зарубіжних джерел, зокрема таких як: Рекомендації № 2006/962/СС Європейського Парламенту і Ради від 18.12.2006 року "Про основні професійні навички, необхідні для отримання освіти протягом усього життя"; Рекомендації Європейського Парламенту і Ради № 2008/С 111/01 від 23.04.2008 року "Про встановлення Європейської кваліфікаційної структури для можливості отримати освіту протягом усього життя"; Рішення Європейського парламенту та Ради № 1720 від 15.11.2006 р. "Про створення програми дій в області навчання впродовж життя", виявлено, що дотичними до поняття "неперервна освіта" є поняття:

- "освіта протягом усього життя" (Lifelong Education) - це цілеспрямовані процеси навчання, виховання, розвитку і саморозвитку, а також результат цих процесів, який не характеризується статичністю, оскільки зазнає постійного оновлення, розширення, поглиблення, уточнення на всіх етапах фізіологічного існування індивіда;

- "навчання для подальшого життя" (Later Life Training) та "навчання протягом усього життя" (Lifelong Learning) - це діяльність того, хто навчається, тобто учня (дорослого учня), із засвоєння інформації, необхідної для ефективного здійснення пізнавальної, навчальної і фахової діяльності у безпосередній або опосередкованій взаємодії з тим, хто навчає;

- "безперервне навчання" (Lifelong Learning) - "вся навчальна діяльність, здійснювана протягом усього життя, з метою поліпшення знань, навичок та компетентностей у межах особистої, громадянської, соціальної та (або) перспективи, пов'язаної із зайнятістю" (Making a European Area of Lifelong Learning a Realit, Брюссель, 21.11.2001 p. СОМ (2001));

- "перманентна освіта" (education permanente) - від лат. permanent - постійний, франц. permanent постійний, безперервний; освіта, яка здійснюється безперервно, триває постійно).

Мета статті полягає в науковому поясненні суті поняття "неперервна освіта" на основі розкриття іiі концептуальних основ, підходів до тлумачення як принципу та процесу, формулювання мети, функцій та етапів їі реалізації.

Виклад основного матеріалу. Концептуальні основи неперервної освіти сформульовано в низці концепції, які було розроблено наприкінці XX століття та на початку XXI століття. Приміром, у Концепції неперервної освіти 1989 року [1] йдеться про: 1) більш раціональний розподіл періодів навчання й трудової діяльності людини впродовж усього життя; 2) навчання в період початкової, або базової освіти і наступної, або після базової освіти; 3) набуття необхідних людині умінь, навичок, знань, якостей, ціннісних орієнтації в міру виникнення потреби в них.

У Концепції розвитку освіти дорослих в Україні (автор Л. Сігаєва; 2009 р.) зазначається, що "освіта дорослих має бути процесом неперервним, це як соціальний самозахист і необхідність, де кожна людина, без огляду на своє матеріальне положення й релігійний світогляд, має право на власний шлях здобуття освіти від дитинства до пізньої старості, як шлях інтелектуального й професійного оновлення" [2: 29-30]. 
Концепцію освіти дорослих в Україні (автор Л. Лук’янова; 2010 р.) спрямовано на "подолання суперечностей: між об’єктивною потребою розвитку навчання дорослих у системі формальної, неформальної й інформальної освіти та нерозробленістю належного нормативно-правового, науковометодичного, організаційного забезпечення; необхідністю врахування потреб ринку праці, вимог роботодавців, а також освітньо-культурних потреб дорослих, мотиваційних, ціннісних орієнтацій дорослих громадян щодо особистісної самореалізації та відсутністю сучасних технологій їхньої професійної підготовки і перепідготовки; зрослими вимогами роботодавців до рівня професійної компетентності працівників і відсутністю комплексної науково обгрунтованої системи організації їхньої професійної перепідготовки" [3: 9-10]

На основі аналізу тлумачень поняття "неперервна освіта", наведених у наукових джерел, можемо зробити висновок про те, що трактування суті неперервної освіти здійснено з різними акцентами, зокрема такими:

- домінуючий акцент на складності феномену (цілеспрямована діяльність та принцип, що пронизує й об'єднує всю систему освіти, всі канали виховного впливу (М. Солдатенко); спеціально організоване навчання і самоосвіта впродовж життя (Н. Мойсеюк));

- домінуючий акцент на процесі (цілеспрямований, послідовний процес, який супроводжує все людське життя; закономірність суспільного розвитку, в якому процес освіти кожного індивіда як самоцінності $€$ основним ресурсом створення справді гуманістичного суспільства (В. Олійник); безперервний і цілеспрямований процес (Є. Чернишова, Н. Гузій, В. Ляхоцький); процес, який охоплює все життя людини (Г. Шевченко); процес, що забезпечує поступовий розвиток творчого потенціалу особистості, всебічне збагачення іï духовного світу (І. Носаченко));

- домінуючий акцент на динаміці процесу (освіта впродовж всього життя, що передбачає постійний перехід на більш високі рівні, якісний і кількісний прогрес (Д. Снигін);

- домінуючий акцент на семантичному полі поняття "освіта" (освіта впродовж життя (А. Поляков);

- домінуючий акцент на психічних утвореннях людини (цілеспрямоване здобування та вдосконалення людиною знань, умінь, навичок, здібностей протягом усього життя (О. Кучерук); основа усебічного розвитку особистості, поступального збагачення iï творчого потенціалу; умова постійного розвитку індивідуального досвіду людини в процесі засвоєння досвіду соціального на усіх етапах життєвого шляху (С. Зінченко)).

Виокремленням домінуючого акценту в розкритті суті неперервної освіти як складного феномену передбачено акцентування уваги на розгляді неперервної освіти $i$ як принципу, $i$ як процесу. Деталізуємо зазначене. Розгляд неперервної освіти як принципу найбільш ємко, на нашу думку, представлено в роботах Л. Лук'янової, М. Солдатенко. Зокрема, за Л. Лук'яновою, неперервна освіта, виступаючи найважливішим соціально-педагогічним принципом, "відображає сучасну тенденцію побудови освіти як цілісної системи, що спрямована на розвиток особистості і становить умову соціального прогресу. По суті, йдеться про новий погляд на освіту, про новий підхід до розуміння значення освіти в сучасному житті" (Лук’янова Л. Б. Концепція освіти дорослих в Україні").

За М. Солдатенком, неперервною освітою, як принципом, передбачається якісно інший тип взаємодії особистості й суспільства, створення і функціонування системи державних, кооперативних, громадських освітніх установ, які могли б забезпечувати постійну загальноосвітню і професійну підготовку, самоосвіту та перекваліфікацію людини з урахуванням іiї бажань, можливостей та потреб суспільства.

Розгляд неперервної освіти, як процесу, потребує визначення низки принципів, з дотриманням яких вибудовується неперервна освіта. О. Владиславлєв [4] до основних принципів неперервної освіти відносить: цілеспрямованість, індивідуалізацію навчання, принцип системності. У працях О. Кашуби та А. Мушиньскі йдеться про принципи, які відображають основні засади функціонування системи освіти, яка триває впродовж життя. Принципи неперервної освіти вони визначають:

1) з огляду на економічний контекст: принцип демократизації, принцип доступності, принцип якості, принцип універсальності, принцип фінансового забезпечення, принцип цілеспрямованості, принцип ефективності, принцип комплексності, принцип інтеграції, принцип диверсифікації, принцип керованості, принцип збалансованості теорії і практики (О. Кашуба);

2) 3 акцентуванням уваги на педагогічному процесі: цілісність, відкритість, доступність, гнучкість, самоорганізованість, порівнюваність отриманих кваліфікацій і можливість їх доповнення (А. Мушиньскі).

На переконання Л. Лук’янової, неперервна освіта, як процес, має вибудовуватися із залученням усіх ланок освітньої системи. Зокрема вчена зазначає, що "пролонговане цілеспрямоване засвоєння особистістю соціокультурного досвіду 3 використанням усіх ланок освітньої системи; дотримання принципів організації чинної системи освіти, освітньої політики, спрямованої на створення умов для навчання людини впродовж усього їі життя; забезпечення логічного взаємозв'язку і наступності різних ланок освіти" [5: 73-75].

У наукових працях відображено різний контент формулювання мети неперервної освіти, як-от: формування у громадян усвідомленої потреби постійно підвищувати свій освітньо-професійний рівень, 
забезпечення доступу до освітніх послуг незалежно від соціальної самоідентифікації та місця проживання (В. Кремень); сприяння творчій активності особистості протягом усього життя (С. Чернишова, Н. Гузій, В. Ляхоцький); поступовий розвиток ії творчого потенціалу та всебічного збагачення духовного світу (Енциклопедія освіти); виживання в сучасному соціумі та самореалізація впродовж життя (Н. Ничкало); постійне задоволення потреб особистості й суспільства в освіті (А. Поляков); цілеспрямоване здобуття та вдосконалення знань, умінь, навичок, здібностей протягом усього життя (О. Кучерук); систематичне поновлення знань, вдосконалення професійної підготовки, задоволення зростаючих духовних потреб (М. Солдатенко); надання кожному суб’єкту можливості реалізувати власний маршрут отримання освіти (Н. Зверєва, М. Соколова); забезпечення конкурентоспроможності кожної людини, запобігання достроковому їі вилученню 3 активної професійної діяльності (Г. Кузнецов, Т. Калюжна).

За Л. Сігаєвою, "неперервна освіта має служити розвитку особистості і в дитинстві, і в ранній юності, і в роки активної трудової діяльності. Завдання неперервної освіти полягає не тільки в збагаченні людини новими знаннями, а й у збереженні ії професійної компетентності та здоров'я впродовж всього життя" [6: 39-40].

Аналіз наукових джерел сприяв класифікації функцій неперервної освіти за такими критеріями:

1) інституційно-професійний критерій (соціальна, економічна, координаційна, селективна, стимулювальна, орієнтаційна, мотиваційна та адаптаційна (О. Кашуба));

2) особистісний критерій (просвітницька, компенсаторна, культуротворча, стимулювальна, орієнтаційна, мотиваційна та адаптаційна);

3) критерій визначення ролі в розвитку суспільного устрою та економіки (соціальна, економічна (отримання економічного блага) (О. Кашуба));

4) критерій дослідження педагогічного спрямування (діагностична, адаптаційна, пізнавальна, розвивальна, виховна, культурологічна, компенсаторна (А. Поляков);

5) полідіяльнісний критерій (соціокультурна, розвивальна, загальноосвітня, компенсаторна, адаптивна, економічна (Н. Ничкало).

Важливим аспектом розкриття суті неперервної освіти, як процесу, є розгляд етапів її розгортання. Слід зазначити, що на основі аналізу наукової літератури нами виокремлено два підходи до їх визначення:

- I підхід - визначення етапів здійснюється на основі широкого розуміння суті феномену, тобто цілісного бачення цього процесу, синонім "освіта впродовж всього життя";

- II підхід - визначення етапів здійснюється на основі вузького розуміння суті феномену, розгляду неперервної освіти в межах професійної підготовки та професійної діяльності (іншими словами неперервна професійна освіта).

Етапами неперервної освіти, яка трактується як освіта впродовж життя, є: "навчання, виховання і розвиток людини, передуючий ії вступу в самостійне життя (дитячо-юнацька освіта); учбова діяльність в період дорослого життя, що поєднана різними видами практичної діяльності (освіта дорослих)" [7: 581583]. Дорослість визначається як стадія розвитку людини, що характеризується зрілістю, бажанням до подальшого саморозвитку особистості, почуттям відповідальності за свої і чужі вчинки; має певний статус у суспільстві і $€$ визнаним ним.

Більш вузькому розумінню суті неперервної освіти слугують такі поняття, як: "неперервна професійна освіта", "неперервна педагогічна освіта", "неперервна освіта дорослих", "неперервна освіта молоді".

Неперервна професійна освіта розглядається як "процес, спрямований на всебічний розвиток особистості, систематичне поповнення знань, умінь і навичок упродовж життя для інтелектуального, культурного і духовного розвитку особистості, удосконалення професійної компетентності та духовних потреб людини. Неперервність професійної освіти виражається в організаційній, змістовій єдності, наступності й взаємозв'язку усіх ланок професійної освіти із урахуванням актуальних, перспективних суспільних та економічних потреб, особистісних прагнень і можливостей. Здійснюється у державних і приватних навчальних закладах, у ході самоосвітньої діяльності" (Л. Лук'янова, О. Аніщенко) [5: 63-65]. "Зміст неперервної професійної освіти дорослих зумовлений, по-перше, потребами суспільства, по-друге - потребами самого фахівця" Т. Десятов [8: 186-189].

Неперервна професійна освіта включає в себе такі етапи: початковий - професійно-орієнтувальний; основний - професійно-формувальний, післядипломний - професійно-супроводжувальний) (Л. Кравченко); допрофесійна підготовка (профільна школа); базова професійна підготовка (бакалаврат) та професійне вдосконалення (навчання за кваліфікаційним рівнем спеціаліста або магістра) (О. Кучерук).

Висновки. Смислова експлікація феномену "неперервна освіта" засвідчила:

- різноаспектне його тлумачення (у даній статті йшлося про неперервну освіту як принцип та як процес, який здійснюється з конкретною метою та виконує певні функції); 
- неперервна освіта як процес розгортається поетапно; визначення етапів здійснюється на основі широкого розуміння суті феномену (це цілісне бачення процесу, що розгортається від народження дитини й триває впродовж її життя) або вузького (розгляду неперервної освіти в межах професійної підготовки та професійної діяльності (іншими словами неперервна професійна освіта));

- необхідність в упорядкуванні понять, які використовуються в наукових джерелах у контексті неперервної освіти. 3 метою реалізації зазначеного нами виокремлено: 1) синонімічні родові поняття "неперервна освіта", "перманентна освіта", "освіта протягом усього життя" (Lifelong Education); 2) синонімічні видові поняття - "навчання для подальшого життя" (Later Life Training), "навчання протягом усього життя" (Lifelong Learning), "безперервне навчання" (Lifelong Learning)); 3) поняття, упорядковані в системі "родове - видове": "неперервна освіта" ("перманентна освіта", "освіта протягом усього життя" (Lifelong Education) - "навчання для подальшого життя" (Later Life Training) ("навчання протягом усього життя" (Lifelong Learning), "безперервне навчання" (Lifelong Learning)).

\section{СПИСОК ВИКОРИСТАНИХ ДЖЕРЕЛ ТА ЛІТЕРАТУРИ}

1. Концепция непрерывного образования // Бюл. Гос. Ком. СССР по нар. образованию. Сер. : Высшие и сред. учеб. заведения. - М., 1989. - № 8. - С. 2-12.

2. Сігаєва Л. Концепція розвитку освіти дорослих в Україні / Л. Сігаєва. - К. : ЕКМО, 2009. - 44 с.

3. Лук'янова Л. Концепція освіти дорослих в Україні /Л. Лук'янова // Освіта дорослих : теорія, досвід, перспективи. - 2010. - Вип. 2. - С. 8-9.

4. Владиславлев А. П. Непрерывное образование: проблемы и перспективы / А. П. Владиславлев. - М. : Молодая гвардия, 1978. - 175 с.

5. Лук'янова Л. Б. Освіта дорослих : короткий термінологічний словник / Авт.-упор. Л. Б. Лук'янова, О. В. Аніщенко. - К. ; Ніжин : Видавець ПП Лисенко М. М., 2014. - 108 с.

6. Сігаєва Л. Є. Розвиток освіти дорослих в Україні (друга пол. ХХ ст. - поч. ХXI ст.) : [монографія] / за ред. С. О. Сисоєвої ; НАПН України, Інститут пед. освіти і освіти дорослих НАПН України. - К. : ТОВ "ВД ЕКМО". - 2010. - $420 \mathrm{c}$.

7. Енциклопедія освіти / Акад. пед. наук України ; головний редактор В. Г. Кремень. - К. : Юрінком Інтер, 2008. - $1040 \mathrm{c}$.

8. Десятов Т. Тенденції розвитку освіти дорослих: Європейський досвід / Т. Десятов // Освіта дорослих: теорія, досвід, перспективи. - 2014. - Вип. 1(8). - 190 с.

\section{REFERENCES (TRANSLATED \& TRANSLITERATED)}

1. Kontseptsiia nepreryvnogo obrazovaniya [Concept of Continuous Education] // Byul. Gos. Kom. SSSR po nar. obrazovaniyu. Ser. : Vysshie i sred. ucheb. zavedeniia [Bul. Gov. Comm. USSR in Common Education. Ser. : High and Secondary Schools]. - M., 1989. - № 8. - S. 2-12.

2. Sigaieva L. Konceptsiia rozvytku osvity doroslykh v Ukraini [Concept of Development of Adult Education in Ukraine] / L. Sigaieva. - K. : EKMO, 2009. - 44 s.

3. Lukianova L. Konceptsiia osvity doroslykh v Ukraini [Concept of Development of Adult Education in Ukraine] / L. Lukianova // Osvita doroslykh : teoriia, dosvid, perspektyvy [Adult Education: Theory, Experience, Perspectives]. - 2010. - Vyp. 2. - S. 8-9.

4. Vladislavlev A. P. Nepreryvnoe obrazovanie: problemy i perspektivy [Continuing Education: Problems and Perspectives] / A. P. Vladislavlev. - M. : Molodaia gvardiia, 1978. - $175 \mathrm{~s}$.

5. Lukianova L. B. Osvita doroslykh : korotkyi terminologichnyi slovnyk [Adult Education : A Short Term Dictionary] / Avt.-upor. L. B. Lukianova, O. V. Anishchenko. - K.; Nizhyn : Vydavec PP Lysenko M. M., 2014. $108 \mathrm{~s}$.

6. Sigaieva L. Ye. Rozvytok osvity doroslykh v Ukraini (druga pol. HH st. - poch. HHI st.) [Development of Adult Education in Ukraine (Second Half of the Twentieth Century - Early XXI Century)] : [monografiia] / za red. S. O. Sysoievoi ; NAPN Ukrainy, Instytut ped. osvity i osvity doroslykh NAPN Ukrainy. - K. : TOV "VD EKMO". $-2010 .-420 \mathrm{~s}$.

7. Encyklopediia osvity [Encyclopedia of Education] / Akad. ped. nauk Ukrainy ; golovnyi redaktor V. G. Kremen. K. : Yurinkom Inter, 2008. - $1040 \mathrm{~s}$.

8. Desiatov T. Tendencii rozvytku osvity doroslyh: Yevropeiskyi dosvid [Trends in Adult Education Development: European Experience] / T. Desiatov // Osvita doroslyh: teoriia, dosvid, perspektyvy [Adult Education: Theory, Experience, Perspectives]. - 2014. - Vyp. 1(8). - 190 s.

\section{Савош В. А. Смысловая экспликация феномена "непрерывное образование": смысл, цель, функции, этапы, выявление на уровнях принципа и процесса.}

В статье осуществлено научное объяснение смысла понятия "непрерывное образование". Анализ толкований понятия "непрерывное образование" упорядочен на основе выделения ряда доминирующих акцентов его трактовок. Сложность феномена "непрерывное образование" раскрыта на основе анализа его толкования и как принципа, и как прочесса.

Также научное объяснение сути понятия "непрерывное образование" направлено на упорядочение ряда понятий, используемых в научных источниках в контексте непрерывного образования. 
Ключевые слова: непрерывное образование, образование, цель, функции, этапь, принцип, процесс.

\section{Savosh V. A. Measuring Expiration Phenomenon "Urgent Education": Content, Purpose, Functions, Stages, Reference at the Level of the Principle and Process.}

The article gives a scientific explanation of the essence of the concept of "continual education". Conceptual bases are disclosed in the context of various concepts (1989 Concept of Continuing Education, Concept of Adult

Education Development in Ukraine (author L. Sigayev, 2009) and Concept of Adult Education in Ukraine (author L. Lukyanova, 2010)). The analysis of the interpretation of the concept of "continuing education" is organized on the basis of the selection of a number of dominant emphases in his interpretations.

The complexity of the phenomenon of "continuing education" is based on the analysis of its interpretation both as a principle and as a process. Continuous education as a principle is characterized in the context of a new view of education, its significance in modern life and the type of interaction of personality and society, which is qualitatively different.

The analysis of continuing education as a process is aimed at highlighting different approaches to: 1) the definition of a number of principles on the basis of which continuous education is built; 2) formulation of the purpose of its implementation; 3) the classification of functions of continuous education according to different criteria; 4) considering the stages of its deployment on the basis of a broad and narrow understanding of the essence of the phenomenon.

Also, the scientific explanation of the concept of "continuing education" was aimed at streamlining a number of concepts (continuing education, continuing professional education (CPE), "recurrent education", "public community education "," adult education "," learning organization ", used in scientific sources in the context of continuing education. This is done on the basis of the selection of synonymous tribal concepts, synonymous species concepts, and understand, arranged in with STEM "family - species."

Key words: continual education, education, purpose, functions, stages, principle, process. 